\title{
Detection of circulating tumor cells in patients with gastrointestinal tract cancer using RT-PCR and its clinical implications
}

\author{
Yun Hee Noh${ }^{1}$, Jung Ah Kim², G-Rewo Lim', \\ Young Tae Ro', Ja Hyun Koo', \\ Yong Sung Lee ${ }^{2}$, Dong Soo Han ${ }^{3}$, \\ Hwon Kyum Park ${ }^{4}$ and Myung Ju Ahn ${ }^{3,5}$ \\ ${ }^{1}$ Department of Biochemistry, College of Medicine, \\ Konkuk University, Chungju 380-791, Korea \\ ${ }^{2}$ Department of Biochemistry, College of Medicine, \\ Hanyang University, Seoul 133-791, Korea \\ ${ }^{3}$ Departments of Internal Medicine and \\ ${ }^{4}$ General Surgery, College of Medicine, \\ Hanyang University Kuri Hospital, Kuri 471-020, Korea \\ ${ }^{5}$ Corresponding author: Tel, +82-31-560-2236; \\ Fax, +82-31-553-7369; E-mail: ahnmj@email.hanyang.ac.kr
}

Accepted 30 January, 2001

Abbreviations: CEA, carcinoembryonic antigen; RT-PCR, reverse transcriptase-polymerase chain reaction; EGC, early gastric cancer; AGC, advanced gastric cancer; B2 or C2, modified Dukes' classification of colorectal cancer

\begin{abstract}
To investigate the relationship between the presence of circulating tumor cells in different stages of gastrointestinal tract cancer and the subsequent relapse or distant metastasis, circulating levels of CEA mRNA was serially examined at an interval of $10.6 \pm 4.5$ or $13.7 \pm 3.0$ months in gastric or colorectal cancer patients, respectively. CEA mRNA was measured by means of RT-PCR amplification as an indicator for micrometastatic malignant cells. Seven of twenty-nine respectable gastric cancer patients (24.1\%) [EGC: $2 / 9$ (22.2\%), AGC Illa: 1/5 (20.0\%), AGC IIlb: $4 / 15(26.6 \%)]$ were positive for CEA mRNA on the initial test and 10 of 29 patients (34.4\%) [EGC: 2/ 9 (22.2\%), AGC IIla: 1/5 (20.0\%), AGC IIIb: 7/15 (46.7\%)] were positive on a follow-up test. Only in AGC IIIb, the positive rate for CEA mRNA increased about twice and 6 of 7 positive cases $(85.7 \%)$ relapsed within $2.6 \pm 2.4$ months after the follow-up test. In colorectal cancer, 4 of 19 patients $(21.1 \%)$ [B2: 1/6 (16.7\%), C2: $3 / 13(23.0 \%)]$ were positive on the initial test and 10 of 19 patients (52.6\%) [B2: 4/6 (66.7\%), C2: $6 / 13(46.2 \%)]$ were positive on a follow-up test
\end{abstract}

showing an increase in positive rates during a follow-up, however, no significant correlation between CEA mRNA positivity and subsequent relapse was demonstrated. These results suggest that an early tumor cell dissemination may occur in gastrointestinal tract cancer without subsequent relapse, however, the serial regular examination of CEA mRNA level may contribute to predicting a subsequent relapse in AGC IIIb in gastric cancer.

Keywords: gastric cancer, colorectal cancer, carcinoembryonic antigen

\section{Introduction}

The prognosis of patients with malignant tumors depends largely on the absence or presence of metastasis. Metastatic tumor cells being probably more invasive and genetically more unstable than those of a primary site (Ruddon, 1995). Metastasis is a multistep process involving numerous host-tumor interactions, in which hematogenous spread of cancer cells from the primary tumor plays a central role (Liotta and Stetler-Stevenson, 1991).

RT-PCR is the most widely used molecular method for the detection of circulating tumor cells (Pelkey et al., 1996). Among the target genes of this aim for RT-PCR, CEA mRNA seems to be the most frequently used for the detection in the blood of patients with gastrointestinal carcinomas (Funaki et al., 1996; Mori et al., 1996; Jonas et al., 1996; Mori et al., 1998; Castells et al., 1998), since it is expressed in almost all epithelial cells, including cancer cells, but not in nonepithelial cells (Shively and Beatty, 1985).

Most of the available data related to the CEA mRNA detection indicate that the presence of circulating tumor cells correlates with the presence of distant metastasis (Funaki et al., 1996; Mori et al., 1996; Jonas et al., 1996; Mori et al., 1998; Castells et al., 1998) and is expected to be associated with a poor prognosis (Hardingham et al., 1995; Mori et al., 1998). But it is still uncertain of its clinical relevance, because a relatively high proportion of non-metastatic gastrointestinal cancer patients was also positive for CEA mRNA (Mori et al., 1996; Mori et al., 1998; Castells et al., 1998). In our previous study, circulating tumor cells were also detected in both EGC (33.3\%) and AGC (18.8\%) and in distant metastatic disease (100\%) (Noh et al., 1999). Interestingly, two 
patients turned into positive result developed an early relapse or multiple distant metastases one or two months later, respectively. Similar cases were reported in lung cancer, in which the patients with positive CEA mRNA without metastasis, developed metastasis within 6 months of analysis (Castaldo et al., 1997). Long-term follow-up data on gastrointestinal tract cancer, however, has not yet been available, and it is, therefore, uncertain whether the presence of circulating tumor cells reliably indicates poor prognosis. In the present long-term follow-up study using CEA mRNA detection by means of RT-PCR, we investigated whether the presence of circulating tumor cells in different stages of gastrointestinal tract reliably indicates subsequent recurrence or distant metastasis.

\section{Patients and Methods}

\section{Patient populations}

The study population consisted of 57 patients with gastrointestinal tract cancers including 36 gastric (14 EGC and 22 AGC) and 21 colorectal cancer (6 Dukes' B, 15 Dukes' C), undergoing surgery and follow-up from June, 1996 to June, 2000 at Hanyang University Kuri Hospital (Kuri, South Korea). The initial test was performed 11.5 \pm 11.1 months (in gastric cancer) and $6.0 \pm 1.4$ months (in colorectal cancer) after operation respectively in order to avoid a transient introduction of tumor cells into the circulation due to surgical manipulation (Mori et al., 1996) and to escape from the influence of chemotherapeutic agents. After a follow-up study we were able to obtain experimental data from 29 gastric (9 EGC and 20 AGC) and 19 colorectal (6 Dukes' B, 13 Dukes' C) cancer patients. The tumor, node, metastases system (TNM) classification was used for gastric cancer and Dukes' classification for colorectal carcinoma. In this study, patients with distant metastasis were excluded from the beginning, because several reports have demonstrated that CEA mRNA positivity significantly correlates with the presence of distant metastasis, similar to our previous study (Mori et al., 1998; Castells et al., 1998; Noh et al., 1999). All patients who had undergone curative surgery followed postoperative pathological staging. Clinical followup studies include abdominal and/or pelvic CT or ultrasonography, gastro- or colonoscopy, chest PA, serum CEA, and bone scan. Fifteen normal healthy subjects were tested as a negative control. Informed consent was obtained from each patient.

\section{Cell lines and peripheral blood samples}

As described in our earlier study (Noh et al., 1999), a colon cancer cell line, Colo 201 (purchased from Korean Cell Line Bank, Seoul, South Korea) was used to test the potential sensitivity of RT-PCR in the detection of circulating tumor cells. Mononuclear cells in $14 \mathrm{ml}$ of peripheral blood obtained from normal healthy donors and patients were separated by Ficoll-Hypaque.

\section{RNA preparation}

Total RNA from peripheral mononuclear cells or Colo 201 cells was extracted by thiocyanate, phenol-chloroform method described by Chomczynski and Sacchi (Chomczynski and Sacchi, 1987). RNA was spectrophotometrically quantified at $260 / 280 \mathrm{~nm}$, and its quality was examined in $1 \%$ agarose gel to find intact $28 \mathrm{~S}$ and 18S RNAs.

\section{RT-PCR}

Five micrograms of total RNA were pre-incubated for 10 min at $70^{\circ} \mathrm{C}$. After chilling on ice, first-strand cDNA was synthesized in a $25 \mu$ reaction mixture containing $5 \mu \mathrm{l}$ of $5 \times$ reverse transcriptase reaction buffer (Promega, Madison, WI, USA), $200 \mu \mathrm{M}$ dNTP, $100 \mu \mathrm{M}$ of random hexamer, 50 units of RNasin (Promega, Madison, WI, USA), $2 \mu$ l of $0.1 \mathrm{M}$ dithiothreitol, and 200 units of MoloneyMurine Leukemia Virus (MMLV) reverse transcriptase (Promega, Madison, WI, USA). The mixture was incubated at $37^{\circ} \mathrm{C}$ for $60 \mathrm{~min}$, heated at $95^{\circ} \mathrm{C}$ for $10 \mathrm{~min}$, and then chilled on ice. CEA specific oligonucleotide primers used for nested PCR were synthesized according to published sequence information (Schrewe et al., 1990; Gerhard et al., 1994): A, 5'-TCTGGAACTTCTCCTGGTCTCTCAGCTGG-3'; B, 5'-TGTAGCTGTTGCAAATGCTTTAAGGAAGAAGC-3'; and C, 5'-GGGCCACTGTCGGCATCATGATTGG-3'. The first and second PCR products exhibited a $160 \mathrm{bp}$ fragment and a 131 bp fragment respectively. The nested PCR was performed according to the method described by Gerhard et al. (1994). The first PCR was carried out in a reaction mixture $(80 \mu \mathrm{l})$ containing $8 \mu \mathrm{l}$ of $10 \times$ reaction buffer [500 mM KCl, $100 \mathrm{mM}$ Tris- $\mathrm{HCl}\left(\mathrm{pH} 9.0\right.$ at $\left.25^{\circ} \mathrm{C}\right)$, and 1.0\% Triton X-100], 2.5 unit of Taq polymerase (Promega, Madison, WI, USA), $2.5 \mathrm{mM} \mathrm{MgCl}_{2}, 200 \mu \mathrm{M}$ dNTP, 25 pmole primers $A$ and $B$, and $8 \mu$ of template cDNA. Thirty-five cycles of amplification were performed in a thermocycler (Robocycler 40: Stratagene, La Jolla, CA, USA) at $95^{\circ} \mathrm{C}$ for $1 \mathrm{~min}$, and $72^{\circ} \mathrm{C}$ for 2 min with a final extension step performed for $10 \mathrm{~min}$ at $72^{\circ} \mathrm{C}$. Five microliters of the reaction mixture were transferred into a second eppendorf tube containing $200 \mu \mathrm{M}$ dNTP, 1.5 $\mathrm{mM} \mathrm{MgCl}$, 2.5 units of Taq polymerase and 20 pmoles of primer $\mathrm{B}$ and $\mathrm{C}$. Thirty-five cycles were performed at $95^{\circ} \mathrm{C}$ for $1 \mathrm{~min}, 69^{\circ} \mathrm{C}$ for $1 \mathrm{~min}$, and $72^{\circ} \mathrm{C}$ for $1 \mathrm{~min}$, with a final extension step for $10 \mathrm{~min}$ at $72^{\circ} \mathrm{C}$.

To ensure sufficient purity of RNA for RT-PCR, a separate round of PCR with primers specific for the gene $\beta$-actin cDNA was carried out in each case. The primer sequences for $\beta$-actin cDNA were as follows: 5 'TGACGGGGTCACCCACACTGTGCCCATCTA-3' and 
5'-CTAGAAGCATTGCGGTGGACGATGGAGGG-3'.

Each series of RT-PCR included an RNA-omitted sample to rule out the possibility of the genomic DNA contamination, normal healthy blood sample as a negative control, and a total RNA sample of Colo 201 cells as a positive control.

\section{Statistical analysis}

Continuous variables were expressed as mean \pm standard deviations. For statistical analysis, age was dichotomized at the median. Differences in relative frequency of CEA mRNA positive cases and correlation between qualitative variables were evaluated using Fisher's exact test. We considered $P$ value of 0.05 as the criterion for statistical significance.

\section{Results}

\section{Sensitivity of tumor marker CEA mRNA detection}

Each dilution of control cancer cells, Colo 201, was mixed with $10^{6}$ mononuclear cells obtained from the peripheral blood of healthy volunteers. As described in our earlier study (Noh et al., 1999), CEA mRNA at a concentration as low as $10^{1}$ Colo 201 cells $/ 10^{6}$ normal mononuclear cells could be detected with the same sensitivity as described (Gerhard et al., 1994; Mori et al., 1995).

\section{Results of RT-PCR and clinical data}

None of the 15 normal subjects were positive. Among the 29 gastric cancer patients at different stages, 7 patients (24.1\%) [EGC: $2 / 9$ (22.2\%), AGC Illa: 1/5 (20.0\%), AGC Illb: 4/15 (26.6\%)] were positive for CEA mRNA on the initial test and 10 patients (34.4\%) [EGC: $2 / 9$ (22.2 $\%)$, AGC IIla: 1/5 (20.0\%), AGC IIlb: 7/15 (46.7\%)] on follow-up test (Table 1,2). Representative results are shown in Figure 1. The initial study was done $11.5 \pm$ 11.1 months after curative operation and the follow-up test $10.6 \pm 4.5$ months after the initial test. During the follow-up, there was no change in positive rates in EGC and AGC IIIa, but positive rates were increased from $26.6 \%$ (4 of 15 ) to $46.7 \%$ (7 of 15 ) in AGC Illb (Table 2). In addition, none of the patients with EGC and AGC IIla developed recurrence or distant metastases irrespective of positivity, but 7 of 15 AGC Illb patients (46.7\%) relapsed and 6 of them (85.7\%) were positive cases (Table 3). Most of AGC Illb showing negative results did not develop recurrence or distant metastasis (7 of 8 , $87.5 \%$ ) except one patient, who relapsed one month after the follow-up test (Table 3). Regarding characteristics of relapsed patients, they were all with AGC IIIb and positive for CEA mRNA except one patient, and relapsed within $2.6 \pm 2.4$ (range 1-8) months after the follow-up test. The average duration between operation date (OPD) and relapse was $25.7 \pm 11.0$ (range 16-49)
Table 1. Characteristics of gastric cancer patients

\begin{tabular}{|c|c|c|c|c|c|}
\hline \multirow{2}{*}{$\frac{\text { Patient }}{1}$} & \multirow{2}{*}{$\begin{array}{c}\text { Age } \\
63\end{array}$} & \multirow{2}{*}{$\frac{\text { Sex }}{F}$} & \multicolumn{2}{|c|}{$\begin{array}{c}\text { Status } \\
(\text { Initial } \rightarrow \text { FU*) }\end{array}$} & \multirow{2}{*}{$\begin{array}{c}\text { CEA mRNA } \\
\left(\text { Initial test } \rightarrow \text { FU test }^{\dagger}\right) \\
+-\end{array}$} \\
\hline & & & EGO & $N R$ & \\
\hline 2 & 37 & $M$ & EGO & NR & +- \\
\hline 3 & 45 & $M$ & EGO & NR & -- \\
\hline 4 & 38 & M & EGO & NR & -- \\
\hline 5 & 43 & $\mathrm{~F}$ & EGC & NR & -+ \\
\hline 6 & 42 & $M$ & EGC & NR & -- \\
\hline 7 & 74 & $\mathrm{~F}$ & EGO & NR & -+ \\
\hline 8 & 55 & M & EGC & NR & -- \\
\hline 9 & 33 & $\mathrm{~F}$ & EGO & NR & -- \\
\hline 10 & 67 & $M$ & IIlb & Relapsed $^{\ddagger}$ & -- \\
\hline 11 & 51 & M & IIlb & Relapsed & -+ \\
\hline 12 & 52 & M & Illb & Relapsed & -+ \\
\hline 13 & 59 & $\mathrm{~F}$ & IIlb & $\mathrm{NR}$ & -- \\
\hline 14 & 65 & $\mathrm{~F}$ & Illa & NR & -+ \\
\hline 15 & 62 & M & Illb & Relapsed & -+ \\
\hline 16 & 65 & M & IIla & NR & -- \\
\hline 17 & 63 & $M$ & Illa & Relapsed & -+ \\
\hline 18 & 60 & $F$ & Illa & NR & -- \\
\hline 19 & 58 & M & IIllb & Relapsed & ++ \\
\hline 20 & 34 & $\mathrm{~F}$ & IIllb & NR & -- \\
\hline 21 & 65 & M & Illb & Relapsed & -+ \\
\hline 22 & 55 & $M$ & IIla & NR & +- \\
\hline 23 & 71 & $M$ & IIlb & NR & -- \\
\hline 24 & 63 & $M$ & IIllb & NR & +- \\
\hline 25 & 49 & $\mathrm{~F}$ & IIlb & NR & -- \\
\hline 26 & 58 & $\mathrm{~F}$ & IIllb & NR & +- \\
\hline 27 & 43 & M & IIlb & NR & +- \\
\hline 28 & 63 & M & Illa & NR & -- \\
\hline 29 & 45 & M & Illb & NR & -+ \\
\hline
\end{tabular}

CEA, carcinoembryonic antigen; EGC, early gastric cancer; NR, not relapsed; Illa or Illb, TNM (tumor, node, metastasis) stage; FU, follow-up; "followed up until June, 2000; $\uparrow$ carried out $10.6 \pm 4.5$ months after the initial study; † distant and local.

Table 2. Positive rates of CEA mRNA in gastric cancer

\begin{tabular}{ccc}
\hline TNM stage & $\begin{array}{c}\text { Initial" }(\%) \\
(\mathrm{n}=29)\end{array}$ & $\begin{array}{c}\mathrm{FU}^{\dagger}(\%) \\
(\mathrm{n}=29)\end{array}$ \\
\hline EGC & $2 / 9(22.2)$ & $2 / 9(22.2)$ \\
AGC IIIa & $1 / 5(20.0)$ & $1 / 5(20.0)$ \\
AGC IIIb & $4 / 15(26.6)$ & $7 / 15(46.7)$ \\
Total & $7 / 29(24.1)$ & $10 / 29(34.4)$ \\
\hline
\end{tabular}

EGC, early gastric cancer; AGC, advanced gastric cancer; Illa or Illb, TNM (tumor, node, metastasis) stage; FU, follow-up; "The initial test was done $11.5 \pm 11.1$ months after curative operation.; $†$ The follow-up test was done $10.6 \pm 4.5$ months after the initial test.

months.

In colorectal cancer, 4 of 19 (21.1\%) [B2: 1/6 (16.7\%), C2: $3 / 13(23.0 \%)]$ were positive on the initial test and 10 of $19(52.6 \%)$ [B2: $4 / 6(66.7 \%), \mathrm{C} 2: 6 / 13(46.2 \%)]$ on follow-up test (Table 4,5$)$. Representative results are shown in Figure 2. The initial study was done $6.0 \pm 1.4$ 

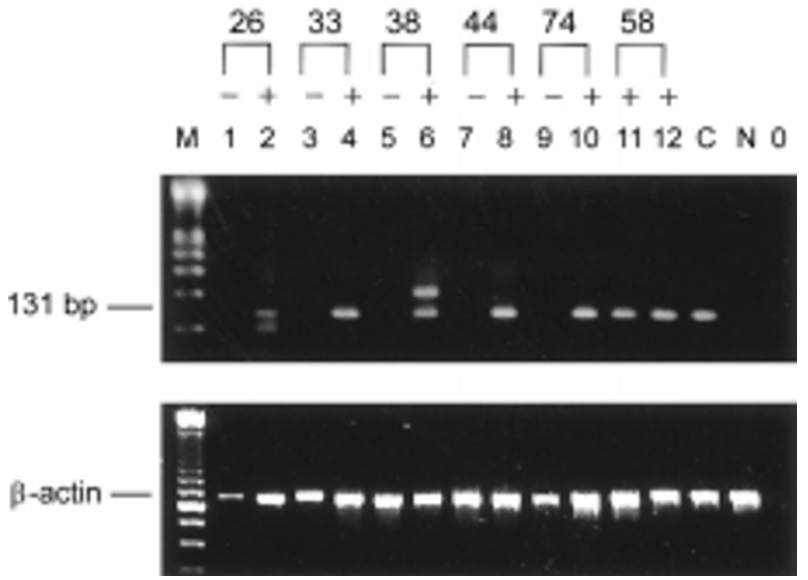

Figure 1. Representative RT-PCR data for CEA mRNA in gastric cancer patients. M, 100 bp ladder DNA size marker; Lanes of the odd numbers, initial test; Lanes of the even numbers, follow-up test; C, Colo 201 as a positive control; N, normal healthy subject; 0 , RNA-omitted sample as a negative control; Number 26, 33, 38,44, 74, and 58, patient No. 5, 12, 15, 17,21 , and 19 , respectively (Table 1); $\beta$ actin serves as an internal control. The additional bands at 100 and $200 \mathrm{bp}$ regions in lane 2 and 6 , respectively, suggest the presence of further subclones or splice variants of CEA in these samples.

Table 3. Results of follow-up test in AGC Illb cases

\begin{tabular}{ccc}
\hline & \multicolumn{2}{c}{ CEA mRNA } \\
& $\begin{array}{c}\text { Positive }(\%) \\
(\mathrm{n}=7)\end{array}$ & $\begin{array}{c}\text { Negative }(\%) \\
(\mathrm{n}=8)\end{array}$ \\
\hline Relapsed* $(\mathrm{n}=7)$ & $6(85.7)$ & $1(12.5)$ \\
NR $(\mathrm{n}=8)$ & $1(14.3)$ & $7(87.5)$ \\
\hline
\end{tabular}

CEA, carcinoembryonic antigen; AGC, advanced gastric cancer; IIlb, TNM (tumor, node, metastasis) stage; NR, not relapsed; "distant and local.

months after curative operation and the follow-up test $13.7 \pm 3.0$ months after the initial test. There was an increase in positive rates during follow-up in all stages tested (Table 5), however, the relapsed was noted only in Dukes' C2 patients, slightly little more in patients with negative CEA mRNA (Table 6). The relapsed patients were all with Dukes' $\mathrm{C} 2$ and developed irrespective of positivity or negativity within $1.4 \pm 0.8$ (range $1-3$ ) months after the follow-up test. The average duration between OPD and relapse was $21.8 \pm 8.0$ (range 13-32) months. In summary, CEA mRNA positivity significantly correlates with the cancer stages [AGC IIIb vs. EGC and AGC IIla in gastric cancer $(P=0.005) ; \mathrm{C} / \mathrm{B} 2$ and $\mathrm{C} / \mathrm{C} 2$ vs $\mathrm{R} / \mathrm{B} 2$ and $\mathrm{R} / \mathrm{C} 2$ in colorectal cancer $(P=0.005)$ ], but not with age or sex. However, it was noted only in AGC Illb that CEA mRNA positivity was correlated with the subsequent relapse. In colorectal cancer, positive results were shown more in patients with colon cancer than in those with rectal cancer, but relapse developed more in rectal cancer than in colon cancer, suggesting no correlation between positivity of CEA mRNA and subsequent relapse.
Table 4. Characteristics of colorectal cancer patients

\begin{tabular}{cccccc}
\hline Patient & Age & Sex & $\begin{array}{c}\text { Status } \\
(\text { Initial } \rightarrow \text { FU*) }\end{array}$ & $\begin{array}{c}\text { CEA mRNA } \\
\left(\text { Initial test } \rightarrow \text { FU test }{ }^{\dagger} \text { ) }\right.\end{array}$ \\
\hline 1 & 59 & M & C/B2 & NR & -- \\
2 & 64 & F & C/B2 & NR & -+ \\
3 & 60 & M & C/B2 & NR & -+ \\
4 & 57 & M & R/B2 & NR & -- \\
5 & 46 & M & R/B2 & NR & ++ \\
6 & 67 & F & C/B2 & NR & -+ \\
7 & 50 & F & R/C2 & NR & -- \\
8 & 57 & M & R/C2 & Relapsed & -- \\
9 & 41 & M & R/C2 & Relapsed & -- \\
10 & 38 & F & C/C2 & NR & -+ \\
11 & 60 & F & R/C2 & Relapsed & -- \\
12 & 34 & M & C/C2 & NR & -+ \\
13 & 34 & M & C/C2 & NR & ++ \\
14 & 45 & F & R/C2 & NR & ++ \\
15 & 48 & F & R/C2 & Relapsed & -+ \\
16 & 24 & M & R/C2 & NR & -- \\
17 & 26 & M & R/C2 & NR & +- \\
18 & 57 & F & R/C2 & NR & -- \\
19 & 63 & F & C/C2 & Relapsed & -+ \\
\hline
\end{tabular}

CEA, carcinoembryonic antigen; C/B2 or C/C2, colon cancer Dukes' B2 or C2; R/B2 or R/C2, rectal cancer Dukes' B2 or C2; NR, not relapsed; FU, follow-up; "followed up until June, 2000; † carried out 13.7 \pm 3.0 months after the initial study; $\ddagger$ distant and local.

Table 5. Positive rates of CEA mRNA in colorectal cancer

\begin{tabular}{ccc}
\hline $\begin{array}{c}\text { Dukes' } \\
\text { classification }\end{array}$ & $\begin{array}{c}\text { Initial* }(\%) \\
(\mathrm{n}=19)\end{array}$ & $\begin{array}{c}\mathrm{FU}^{\dagger}(\%) \\
(\mathrm{n}=19)\end{array}$ \\
\hline B2 & $1 / 6(16.7)$ & $4 / 6(66.7)$ \\
C2 & $3 / 13(23.0)$ & $6 / 13(46.2)$ \\
Total & $4 / 19(21.1)$ & $10 / 19(52.6)$ \\
\hline
\end{tabular}

CEA, carcinoembryonic antigen; FU, follow-up; "The initial test was done $6.0 \pm 1.4$ months after curative operation; $\dagger$ The follow-up test was done $13.7 \pm 3.0$ months after the initial test.

\section{Discussion}

Studies on the detection of micrometastasis to bone marrow or lymph nodes in solid cancers revealed that it can be used as a useful method for predicting prognosis because the risk for tumor relapse increases with the presence of micrometastasis (Dearnaley et al., 1991; Neville, 1991; Schlimok et al., 1991; Pelkey et al., 1996). However, the clinical significance of micrometastasis to blood has not been determined yet in spite of many related studies (Hardingham et al., 1995; Funaki et al., 1996; Jonas et al., 1996; Mori et al., 1996; Castells et al., 1998; Mori et al., 1998). It was reported in 1970 that the vast majority of circulating tumor cells shed from solid tumors do not survive in the blood, and only about $0.1 \%$ live long enough to form a distant metastasis (Fidler, 1970). Hence, the presence of tumor cells in the blood does not necessarily indicate that distant metastasis will 

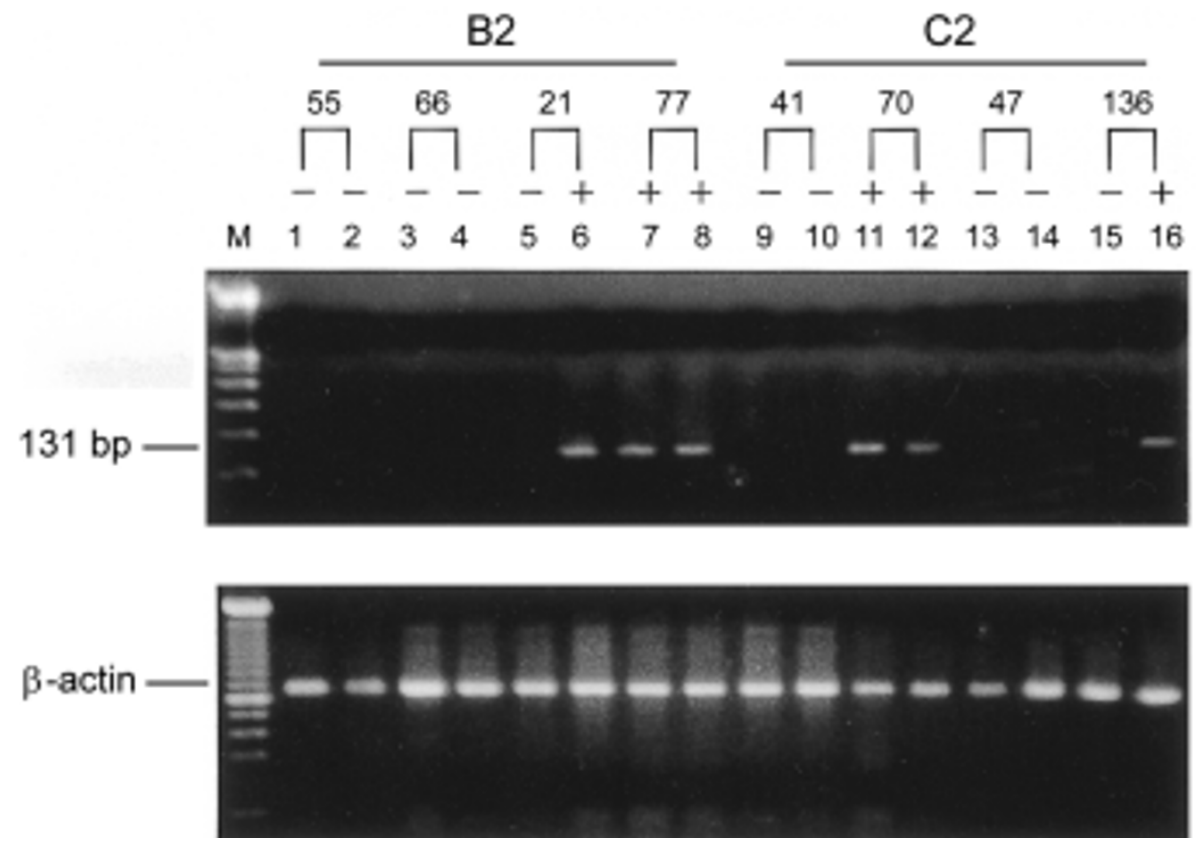

Figure 2. Representative RT-PCR data for CEA mRNA in colorectal cancer patients. M, 100 bp ladder DNA size marker; Lanes of the odd numbers, initial test; Lanes of the even numbers, follow-up test; B2 or C2, Dukes' classification; Number 55, 66, 21, 77, 41, 70, 47, and 136, patient No. 4, 1, 2, 5, 7, 13, 9, and 19, respectively (Table 4); $\beta$ actin served as an internal control.

Table 6. Results of follow-up test in colorectal cancer C2

\begin{tabular}{ccc}
\hline & \multicolumn{2}{c}{ CEA mRNA } \\
& $\begin{array}{c}\text { Positive (\%) } \\
(n=6)\end{array}$ & $\begin{array}{c}\text { Negative }(\%) \\
(n=7)\end{array}$ \\
\hline Relapsed $^{*}(n=5)$ & $2(33.3)$ & $3(42.9)$ \\
NR $(n=8)$ & $4(66.7)$ & $4(57.1)$ \\
\hline
\end{tabular}

CEA, carcinoembryonic antigen; C2, Dukes' classification; NR, not relapsed; "distant and local.

form (Ruddon, 1995) and more than a simple presence of tumor cells in the blood stream is involved in metastasis formation (Rinker-Schaeffer et al., 1994; Ruddon, 1995; Pelkey et al., 1996). Liotta and Stetler-Stevenson (1991), however, reported hematogenous spread of cancer cells from the primary site constitutes a key point in metastasis.

In our previous study (Noh et al., 1999), we found that the identification of circulating tumor cells by detecting CEA mRNA using RT-PCR was feasible, as shown also by other studies (Funaki et al., 1996; Jonas et al., 1996; Mori et al., 1996; Castells et al., 1998; Mori et al., 1998). Using this method, we found that metastatic gastric cancer patients tested were all positive for CEA mRNA in peripheral blood, but $33.3 \%$ of early gastric cancer patients were also positive. The current study also demonstrated that $22.2 \%$ of EGC and $66.7 \%$ of Dukes' B2 colorectal cancer at the follow-up test were positive for CEA mRNA (Tables 2 and 5), indicating that cancer cells can disseminate even in the early stage of gastrointestinal cancer and supporting the hypothesis that gastrointestinal cancers might be considered as systemic diseases as breast cancer (Heiss et al., 1995; Mori et al., 1996).

Even though the durations of follow-up until June, 2000 of these EGC and Dukes' B2 colorectal cancer patients are $31.1 \pm 12.7$ (range 11-48) and $29.5 \pm 4.3$ (range 2538) months, respectively, further follow-up with a larger population appears to be needed to elucidate whether the positivity for CEA mRNA in early-stage patients correlates with recurrence or distant metastasis.

Mori et al. reported the frequency of positive cases for CEA mRNA increased with advanced stage of disease in gastric or colorectal cancers (Mori et al., 1996; Mori et al., 1998). Interestingly, there have been some reports suggesting the correlation between positivity for CEA mRNA in the peripheral blood and subsequent relapse, e.g., three of 4 positive patients with far-advanced pancreatic carcinoma developed recurrence after curative operation or liver metastasis after mass-reducing operation within 9 months after the analysis (Funaki et al., 1996), two of 4 positive patients without the evidence of distant metastasis developed metastasis within a few months (Castaldo et al., 1997). Also in our previous study, one patients with stage III gastric cancer who was negative for CEA mRNA initially and turned positive during follow-up, developed multiple bone metastasis one month later. Another stage III patient who was positive for CEA mRNA preoperatively revealed early relapse in two months. Most of the available data, however, 
simply demonstrated the frequency of positive cases at the different stages of gastrointestinal cancers and small cases showing subsequent relapse, but did not reveal clearly the correlation between the presence of circulating tumor cells and the subsequent relapse due to the lack of long-term study (Funaki et al., 1996; Jonas et al., 1996; Mori et al., 1996; Castells et al., 1998; Mori et al., 1998).

As the first step for the long-term study, we examined CEA mRNA expression in the peripheral blood of patients at around 12 or 6 months after surgery (in gastric or colorectal cancer, respectively), who underwent curative surgery and clinical follow-up (range 12-58 months). About 11 or 14 months after the initial test (in gastric or colorectal cancer, respectively) we performed the followup test and clinically followed up the patients until June, 2000. Our results showed that persistent positive cases were rare (4 of $48,8.3 \%$ ) as compared with the overall positive rates (Tables 2 and 5), suggesting that tumor cells shed from the primary site intermittently (Ghossein et al., 1995) or circulate in clumps. This meant that inhomogeneous distribution of tumor cells within the circulation could prevent them from being sampled invariably (Jonas et al., 1996). Meanwhile, the frequency of positivity increased in AGC IIIb and colorectal cancer with the duration of disease (Tables 2 and 5), suggesting that shedding of tumor cells increases with advanced stages and duration of disease as well, but the pattern seems to be different according to the kind of gastrointestinal cancers. Accordingly, these phenomena need to be exploited for illuminating the biology of tumor cell invasion into the blood stream. Surprisingly, all the relapsed but one were positive cases with AGC IIIb (6 of 7, 85.7\%) and conversely most negative cases with AGC IIIb (7 of $8,87.5 \%$ ) did not relapse (Table 3 ). Only one patient showing negative result developed recurrence of disease in AGC IIlb. None of the patients with EGC or AGC IIla relapsed irrespective of the results (Table 1).

By contrast, in colorectal cancer, these correlations were not noted. Increasing positive rates during followup did not indicate subsequent relapse. On the contrary the relapsed were noted rather more in the patients showing negative for CEA mRNA (Tables 5 and 6).

These results suggest that this analysis should be repeated at some interval to the patients who were diagnosed as being clinically recurrence-free or metastasis-free in AGC IIlb, although it seems to be not so useful in colorectal cancer.

In summary, early tumor cell dissemination occurs in gastrointestinal tract cancer without subsequent relapse and the tumor cells seems to shed from the primary site intermittently. However, the serial regular examination of CEA mRNA appears to predict subsequent relapse in AGC IIIb rather than in colorectal cancer. Finally, simple detection of circulating tumor cells using one target gene like CEA mRNA has limitation to be a reliable prognostic marker. Therefore, search for the new markers to indicate that carcinoma cells in the bloodstream really form metastasis or concomitant use of other markers related to metastatic potential such as proteases, angiogenesis factors, cell motility regulators or cell adhesion molecules will be desirable to disclose the clinical implications of circulating tumor cells in solid tumors.

\section{Acknowledgements}

This work was supported by Konkuk University in 1999.

\section{References}

Castaldo, G., Tomaiuolo, R., Sanduzzi, A., Bocchino, M. L., Ponticiello, A., Barra, E., Vitale, D., Bariffi, F., Sacchetti, L. and Salvatore, F. (1997) Lung cancer metastatic cells detected in blood by reverse transcriptase-polymerase chain reaction and dot-blot analysis. J. Clin. Oncol. 15: 3388-3393

Castells, A., Boix, L., Bessa, X., Gargallo, L. and Pique, J. M. (1998) Detection of colonic cells in peripheral blood of colorectal cancer patients by means of reverse transcriptase and polymerase chain reaction. Br. J. Cancer 78: 1368-1372

Chomczynski, P. and Sacchi, N. (1987) Single step method of RNA isolation by acid guanidium thiocyanate- $\mathrm{POH}$-chloroform extraction. Anal. Biochem. 162: 156-159

Dearnaley, D. P., Ormerod, M. G. and Sloane, J. P. (1991) Micrometastases in breast cancer: long-term follow-up of the first patient cohort. Eur. J. Cancer 27: 236-239

Fidler, I. J. (1970) Metastasis: Quantitative analysis of distribution and fate of tumor emboli labeled with ${ }^{125}$ |-5-iodo-2'deoxyuridine. J. Natl. Cancer Inst. 45: 773-782

Funaki, N. O., Tanaka, J., Kasamatsu, T., Ohshio, G., Hosotani, R., Okino, T. and Imamura, M. (1996) Identification of carcinoembryonic antigen mRNA in circulation peripheral blood of pancreatic carcinoma and gastric carcinoma patients. Life Sci. 59: 2187-2199

Gerhard, M., Juhl, H., Kalthoff, H., Schreiber, H. W., Wagener, C. and Neumaier, M. (1994) Specific detection of carcinoembryonic antigen expressing tumor cells in bone marrow aspirates by polymerase chain reaction. J. Clin. Oncol. 12: 725-729

Ghossein, R. A., Scher, H. I., Gerald, W. L., Kelly, W. K., Curley, T., Amsterdam, A., Zhang, Z. F. and Rosai, J. (1995) Detection of circulating tumor cells in patients with localized and metastatic prostate carcinomas: clinical implications. J. Clin. Oncol. 13: 1195-1200

Hardingham, J. E., Kotasek, D., Sage, R. E., Eaton, M. C., Pascoe, V. H. and Dobrovic, A. (1995) Detection of circulating tumor cells in colorectal cancer by immunobead-PCR is a sensitive prognostic marker for relapse of disease. Mol. Med. 1: $789-794$

Heiss, M. M., Allgayer, H., Gruetzner, K. U., Funke, I., Babic, 
R., Jauch, K. W. and Schildberg, F. W. (1995) Individual development and uPA-receptor expression of disseminated tumour cells in bone marrow: a reference to early systemic disease in solid cancer. Nature Med. 1: 1035-1039

Jonas, S., Windeatt, S., O-Boateng, A., Fordy, C. and AllenMersh, T. G. (1996) Identification of carcinoembryonic antigenproducing cells circulating in the blood of patients with colorectal carcinoma by reverse transcriptase polymerase chain reaction. Gut 39: 717-721

Liotta, L. A. and Stetler-Stevenson, W. G. (1991) Tumor invasion and metastasis: an imbalance of positive and negative regulation. Cancer Res. 51: 5054s-5059s

Mori, M., Mimori, K., Inoue, H., Barmard, G. F., Tsuji, K., Nanbara, S., Ueo, H. and Akiyoshi, T. (1995) Detection of cancer micrometastases in lymph nodes by reverse transcriptase polymerase chain reaction. Cancer 55: 3417-3420

Mori, M., Mimori, K., Ueo, H., Karimine, N., Barnard, G. F., Sugimachi, K. and Akiyoshi, T. (1996) Molecular detection of circulating solid carcinoma cells in the peripheral blood: the concept of early systemic disease. Int. J. Cancer 68: 739-743

Mori, M., Mimori, K., Ueo, H., Tsuhi, K., Shiraishi, T., Barnard, G. F., Sugimachi, K. and Akiyoshi, T. (1998) Clinical significance of molecular detection of carcinoma cells in lymph nodes and peripheral blood by reverse transcription-polymerase chain reaction in patients with gastrointestinal or breast carcinomas. J. Clin. Oncol. 16: 128-132

Neville, A. M. (1991) Breast cancer micrometastasis in lymph nodes and bone marrow are prognostically significant. Ann. Oncol. 2: 13-14
Noh, Y. H., Im, G. R., Koo, J. H., Lee, Y. S. and Ahn, M. J. (1999) Detection of tumor cell contamination in peripheral blood by RT-PCR in gastrointestinal cancer patients. J. Korean Med. Sci. 14: 623-628

Pelkey, T. J., Frierson, H. F. Jr. and Bruns, D. E. (1996) Molecular and immunological detection of circulating tumor cells and micrometastases from solid tumors. Clin. Chem. 42: 1369-1381

Rinker-Schaeffer, C. S., Partin, A. W., Isaacs, W. B., Coffey, D. S. and Isaacs, J. T. (1994) Molecular and cellular changes associated with the acquisition of metastatic ability by prostatic cancer cells. Prostate 25: 249-265

Ruddon, R. W. (1995) Biology of tumor metastasis. In Cancer Biology, 3rd Ed., pp. 405-419, Oxford University Press, New York NY

Schlimok, G., Funke, I., Pantel, K., Strobel, K., Lindemann, F., Witte, J. and Riethmuller, G. (1991) Micrometastatic tumour cells in bone marrow of patients with gastric cancer: methodological aspects of detection and prognostic significance. Eur. J. Cancer 27: 1461-1465

Schrewe, H., Thompson, J., Bona, M., Hefta, L. J. F., Maruya, A., Hassauer, M., Shively, J. E., Von Kleist, S. and Zimmermann, W. (1990) Cloning of the complete Gene for carcinoembryonic antigen: Analysis of its promoter indicates a region conveying cell type-specific expression. Mol. Cell Biol. 10: 2738-2748

Shively, J. E. and Beatty, J. D. (1985) CEA-related antigens: molecular biology and clinical significance. Crit. Rev. Oncol. Hematol. 2: 355-399 